\title{
PILOT STUDY - A STUDY IN SELECTED HOSPITALS TO ASSESS THE EFFECTIVENESS OF TRILOGY IN REDUCING ANXIETY AND WORRIES IN DEPRESSED PATIENTS
}

\author{
Mr. Kodeeswaran A.*| Dr. Savithri K.** \\ * Ph.D. scholar at Himalayan University at Itanagar, Arunachal Pradesh, India. \\ ** Research Guide, Himalayan University at Itanagar, Arunachal Pradesh, India \\ DOI: http://doi.org/10.47211/idcij.2021.v08i01.003
}

\begin{abstract}
India is the most depressed country in the world, according to the world health organisation. Depression is one of the most commonly diagnosed mental disorders in primary care settings. The NMHS provides information on prevalence, disability, treatment gap and socioeconomic impact associated with depressive disorders among adults in India. The crude prevalence rate of mood disorder was estimated to vary from as low as 0.5 to as high as 78 per 1000 population. One in six people aged 10-19 years is suffering from depression. Globally, depression is one of the leading causes of mental illness, suicide and disability among adolescents. Outcomes: The overall comparison in experimental group among tests regarding level of anxiety that paired sample ' $t$ ' test was calculated to significant difference in within group to test scores of level of anxiety in experimental group revealed that there was a highly statistically significant difference found in the level of anxiety in outcome scores between pre and post-1 test in experimental. The overall mean difference between pre test $(29.3 \pm 5.77)$ and post test -1 (20.13 \pm 3.74$)$ group with mean difference was 9.2. The obtained ' $t$ ' value was 10.94 with $p<0.001$ which was statistically highly significant difference between pre test and post test -1 . The overall mean

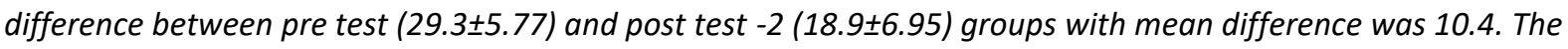
obtained ' $t$ ' value was 10.56 with $p<0.001$ which was statistically highly significant difference between pre and post-2. The overall mean difference between pre test (29.3 \pm 5.77$)$ and post test $-3(14.6 \pm 7.95)$ groups with mean difference was 14.73. The obtained ' $t$ ' value was 12.41 with $p<0.001$ which was statistically highly significant difference between pre test and post test -3. Conclusion:-Hence, Comparison of overall interpretation regarding level of anxiety in experimental group depicts that, there was significant difference found between tests (pre, post-1, post2, and post-3). The findings of the study proved that Art, Dance and Film therapy on depressed patients was effective in reducing the level of anxiety and worries. The study revealed that irrespective of variations in demographic variables, all patients in experimental group showed reduction in level of anxiety and worries with depression.
\end{abstract}

Key Words: prevalence, disability, anxiety, worries with depression.

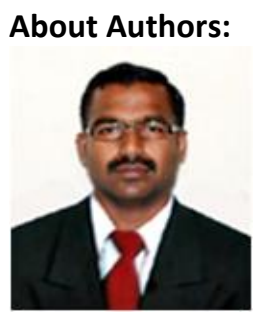

Author Mr. A. Kodeeswaran is a Ph.D. scholar at Himalayan University at Itanagar in the Indian state of Arunachal Pradesh. He has published papers and attended various Seminars and conferences.

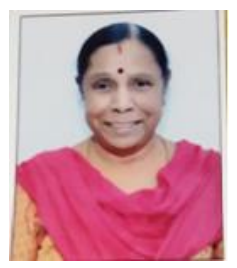

Author Dr. K. Savithri, M.Sc (N), PhD (N), is Research Guide at Himalayan University at Itanagar in the Indian state of Arunachal Pradesh. She has published papers in national and International Journals. She has attended and organised various National and International conferences and has given extensive lectures. 


\section{INTRODUCTION}

Depression is a mood disorder that causes a persistent feeling of sadness and loss of interest. Also called major depressive disorder or clinical depression, it affects how individual feel, think and behave and can lead to a variety of emotional and physical problems. The patient may have trouble doing normal day-to-day activities, and sometimes he may feel as if life isn't worth living. Most people with depression feel better with medication, psychotherapy or both.

\section{NEED FOR STUDY}

WHO estimates that one in four people in the world will be affected by mental or neurological disorders at some point in their lives. Around 450 million people currently suffer from such conditions, placing mental disorders among the leading causes of ill-health and disability worldwide. Globally, the total number of people with depression was estimated to exceed 300 million in 2017 , equivalent to $4.3 \%$ of the world's population. Depression is ranked as the single largest contributor to global disability $(7.5 \%$ of all years lived with disability in 2018). At its worst, depression can lead to suicide, over 800000 people die due to suicide every year. Suicide is the second leading cause of death in 15-29-year-olds.

In India, the National Mental Health Survey 2018-19 reveals that nearly 15\% Indian adults need active intervention for one or more mental health issues and one in 20 Indians suffers from depression. The Indian government's commitment is reflected in the National Mental Health Programme (NMHP), which encompasses life skills training and counselling in educational institutions, workplace stress management and suicide prevention services, among others.

\section{THE WORST SYMPTOM OF DEPRESSION IS SUICIDE}

Avoiding treatment or having an especially severe case of the condition can lead to suicidal thoughts. In the end, suicide represents the worst symptom of depression, seeing how it breaks one of the main principles of human life: the need to survive. In severe cases like these, patients lose all hope and are therefore miserable. The subconscious mind then comes to the conclusion that ending it all is a much better alternative, as opposed to seeking help, continuing treatment, and perhaps even living a normal life in the future.

\section{I) ART THERAPY}

The Research shows that art therapy helps to treat depression by providing a unique way to express feelings that might be difficult to vocalize. Opening up to a complete stranger can often be difficult to do, but given a theme and some art supplies, people are able to channel their emotions and feelings into creative art therapy. Art therapy is a technique rooted in the idea that creative expression can foster healing and mental wellbeing. Art, either creating it or viewing others' art, is used to help people explore emotions, develop selfawareness, cope with stress, boost self-esteem, and work on social skills.

\section{II) DANCE THERAPY}

Dance Movement Therapy (DMT) is the therapeutic use of movement to further the emotional, cognitive, Physical and social integration of the individual, based on the empirically supported premise that the body, mind and spirit are interconnected. A study from the journal The Arts in Psychotherapy (2007) found out that dance therapy had a positive effect on participants experiencing symptoms of depression. Most people understand that dancing can be good for their health: it improves cardiovascular endurance, muscle tone, balance, and coordination. Dance can also boost a person's mood, improve his or her body image, and provide an opportunity for fun that may lower overall depression and anxiety.

III) FILM THERAPY

The film therapy or cinema therapy helps individuals to connect with story lines and the movie characters. In the process they "learn about themselves in more profound ways." Cathartic cinema therapy helps a person access their emotions, for instance if they are in a depression, and may be used early stage in psychotherapy.

\section{CONCEPTUAL FRAME WORK OF THE STUDY}

A conceptual frame work or model is a basic structure or outline of abstract idea image that represent reality. Conceptual frame work is a group of mental images or concepts that are related but relationship is not explicit. The conceptual frame work for the study is based on "general system theory".

General system theory serves as a model for viewing people as interacting with the environment. The theory was developed by Ludwing Von Bertalanffy in 1968. 


\section{ARTIC LES}

\section{REVIEW OF LITERATURE \\ I) REVIEW OF LITERATURE RELATED TO ART THERAPY \\ II) REVIEW OF LITERATURE RELATED TO DANCE THERAPY \\ III) REVIEW OF LITERATURE RELATED TO FILM THERAPY}

\section{METHODOLOGY}

\section{RESEARCH APPROACH}

Quantitative educative - evaluative approach.

\section{RESEARCH DESIGN}

Quasi experimental research design

VARIABLES:-

$>$ INDEPENDENT VARIABLES:

Trilogy: - Art, Dance and Film therapy are the independent variable.

$>$ DEPENDENT VARIABLES:

Level of anxiety and worries among depression patients is the dependent variables.

$>$ EXTRANEOUS VARIABLES:

Age, Gender, Marital Status, Type of family, monthly income, educational qualification, occupation SAMPLE SIZE and Residual are the extraneous variables in this study.

Among 60 samples, 30 were in experimental and 30 were in control group.

SAMPLE TECHNIQUE

Non probability - purposive sampling technique was used in this study

INSTRUMENTS USED FOR DATA COLLECTION

1) Hamilton Anxiety rating Scale

2) Hamilton Depression Rating Scale

3) Level of Satisfaction Scale

DATA ANALYSIS AND INTERPRETATION

EFFECTIVENESS OF TRILOGY IN REDUCING LEVEL OF ANXIETY AND WORRIES AMONG THE DEPRESSED PATIENT IN EXPERIMENTAL \& CONTROL GROUP.

Table 1.1: Comparison of thePre-test, post-test1, post-test2 and post- test 3 of the level of anxiety among the depressed patient in experimental group.

$(\mathrm{N}=\mathbf{3 0})$

\section{LEVEL OF ANXIETY- EXPERIMENTAL GROUP}

\begin{tabular}{|c|c|c|c|c|c|c|}
\hline TEST & MEAN & STANDARD DEVIATON & MEAN DIFFERENCE & 't' VALUE & df & 'p' VALUE \\
\hline Pre-test & 29.3 & 5.77 & \multirow[b]{2}{*}{9.2} & \multirow[b]{2}{*}{10.74} & \multirow[b]{2}{*}{29} & \multirow[b]{2}{*}{$<0.001 * * *$} \\
\hline Post-test 1 & 20.13 & 3.74 & & & & \\
\hline Pre-test & 29.3 & 5.77 & \multirow{2}{*}{10.4} & \multirow{2}{*}{10.56} & \multirow{2}{*}{29} & \multirow[t]{2}{*}{$<0.001 * * *$} \\
\hline Post-test 2 & 18.9 & 6.95 & & & & \\
\hline Pre-test & 29.3 & 5.77 & \multirow[b]{2}{*}{14.73} & \multirow{2}{*}{12.41} & \multirow{2}{*}{29} & \multirow[t]{2}{*}{$<0.001 * * *$} \\
\hline Post-test 3 & 14.6 & 7.95 & & & & \\
\hline
\end{tabular}

$* * *-p<0.001$ highly significant 


\section{ARTIC LES}

Hence, Comparison of overall interpretation regarding level of anxiety in experimental group, it depicts that, there was significant difference found between tests (pre,post-1,post2,post-3). Therefore, accept research hypothesis $\left(\mathrm{H}_{11}\right)$.it was found true difference not by chance .Our intervention shown evidence based effectiveness in our study. Therefore, the mean post-test level of anxiety had significantly lower than the mean pre-test level of anxiety among the depressed subjects in experimental group.

Table 1.2 - Comparison of the Pre-test, post-test1, post-test2 and post- test 3 of thethe level of anxiety among the depressed patient in control group.

( $\mathrm{N}=30$ )

\begin{tabular}{|c|c|c|c|c|c|c|}
\hline \multicolumn{7}{|c|}{ LEVEL OF ANXIETY- CONTROL GROUP } \\
\hline TEST & MEAN & $\begin{array}{l}\text { STANDARD } \\
\text { DEVIATON }\end{array}$ & MEAN DIFFERENCE & 't' VALUE & df & 'p' VALUE \\
\hline Pre-test & 29.86 & 5.16 & \multirow[b]{2}{*}{3.96} & \multirow[b]{2}{*}{4.07} & \multirow[b]{2}{*}{29} & \multirow[b]{2}{*}{$<0.001 * * *$} \\
\hline Post-test 1 & 25.9 & 3.35 & & & & \\
\hline Pre-test & 29.86 & 5.16 & \multirow[b]{2}{*}{5.27} & \multirow[b]{2}{*}{5.61} & \multirow[b]{2}{*}{29} & \multirow{2}{*}{$<0.001 * * *$} \\
\hline Post-test 2 & 24.6 & 3.05 & & & & \\
\hline Pre-test & 29.86 & 5.16 & \multirow{2}{*}{9.53} & \multirow[b]{2}{*}{11.70} & \multirow[b]{2}{*}{29} & \multirow{2}{*}{$<0.001 * * *$} \\
\hline Post-test 3 & 20.33 & 5.26 & & & & \\
\hline
\end{tabular}

$* * *-p<0.001$ highly significant

Hence, Comparison of Overall interpretation regarding level of anxiety in control group depicts that ,there was significant difference found between pre and post -1 tests, However, significant difference was found between post test 2 and post test 3 when compared to pre test, it was found by chance not true difference in this group because of non interventional group..Therefore, accept null hypothesis $\left(H_{10}\right)$. Therefore, The mean post-test level of anxiety were significantly lower than the mean pre-test level of anxiety by chance among the depressed subjects in control group. 
Table 1.3:- Comparison of thePre-test, post-test1, post-test2 and post- test 3 of thethe level of worries among the depressed patient in experimental group.

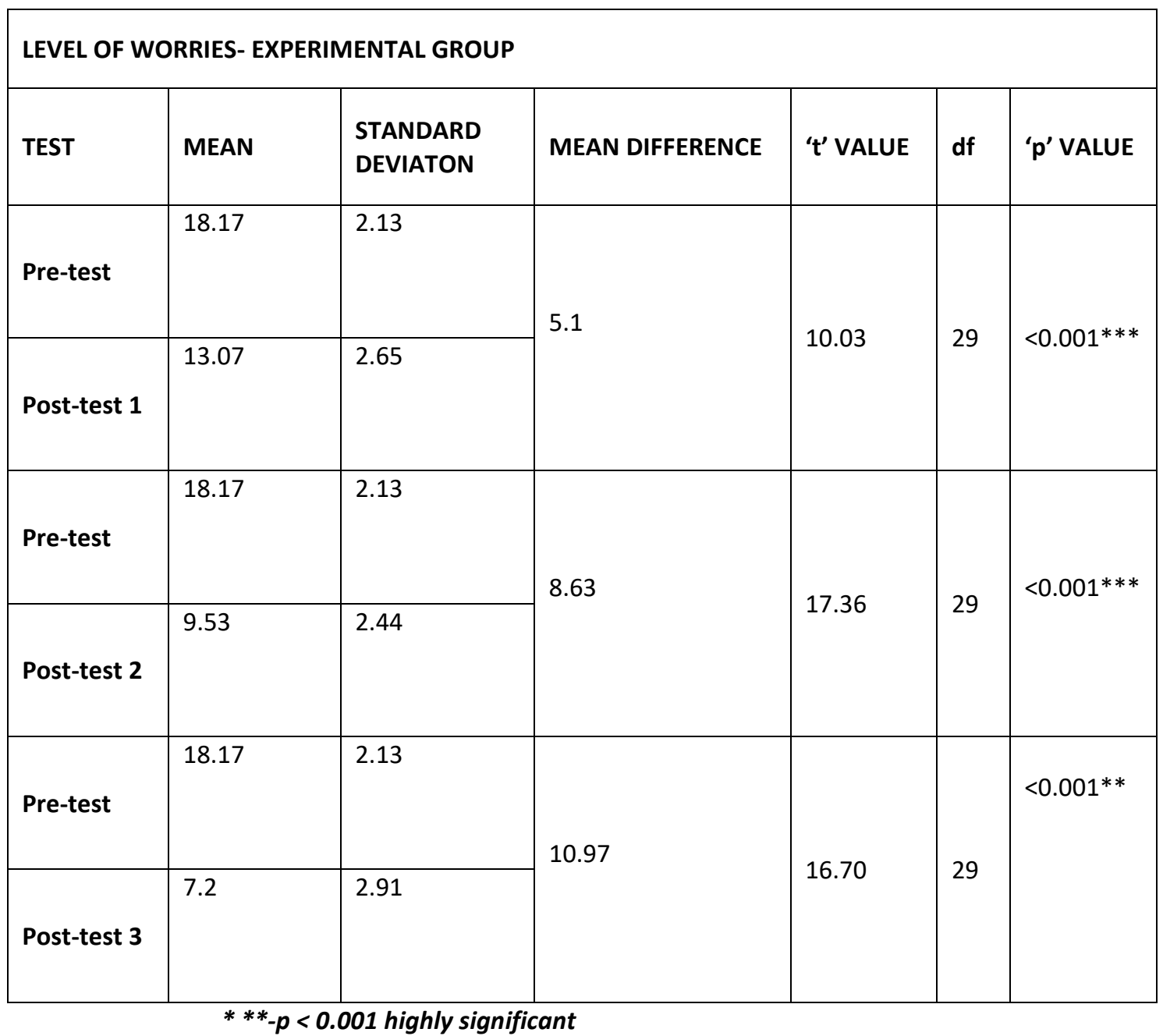

Hence, Comparison of Overall interpretation regarding level of worry in experimental group depicts that, there was significant difference found between tests (pre,post-1,post2,post-3). Therefore, accept research hypothesis $\left(\mathrm{H}_{2}\right)$.it was found true difference not by chance .Our intervention shown evidence based effectiveness of statistical way in our study. Therefore, the mean post-test levels of anxiety significantly lower than the mean pre-test level of worry in experimental group. 
Table 1.4: Comparison of thePre-test, post-test1, post-test2 and post- test 3 of thethe level of worries among the depressed patient in control group

$(\mathrm{N}=\mathbf{3 0})$

${ }^{*} p<0.05$ and $*^{*} *_{-} p<0.001$ highly significant.

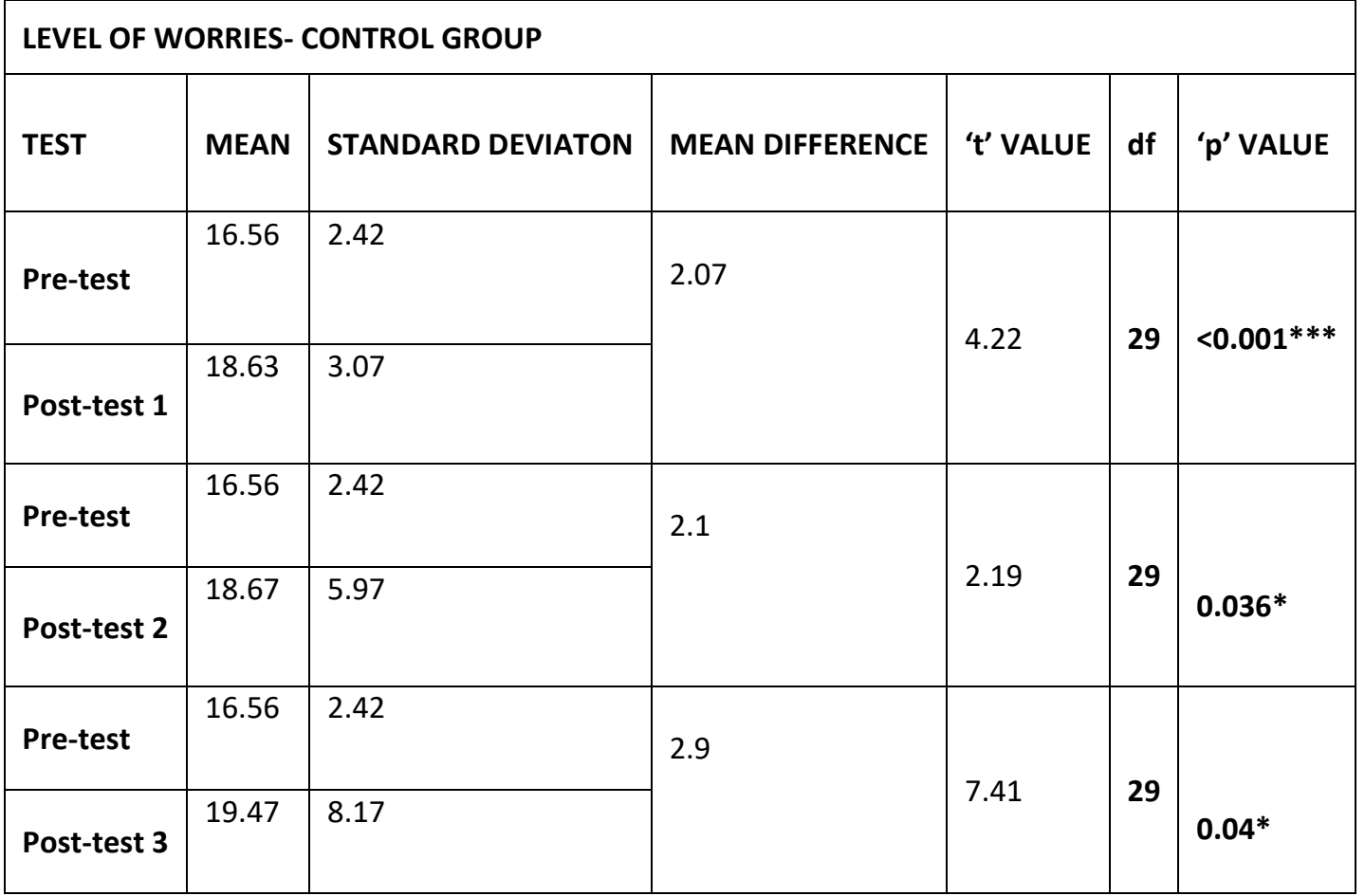

Hence, Comparison of Overall interpretation regarding level of worries in control group depicts that ,there was significant difference found between pre and post -1 tests, post test 2 when compared to pre test, pre and post -3 , whereas it was found by chance not true difference in this control group. Therefore, accept null hypothesis $\left(\mathrm{H}_{20}\right)$. Hence, the mean posttest levels of worries were significantly lower than the mean pretest level of worries among the depressed subjects in control group. 
Table 1.5: Association between the Pre-test of the level of anxiety among the depressed patient with their selected demographic variables in experimental group. $\quad(\mathrm{N}=60)$

\begin{tabular}{|c|c|c|c|c|c|c|c|c|c|c|}
\hline \multirow{3}{*}{\multicolumn{2}{|c|}{ DEMOGRAPHIC VARIABLES }} & \multicolumn{6}{|c|}{ EXPERIMENTAL GROUP } & \multirow[t]{4}{*}{$\mathbf{X} 2$} & \multirow[t]{4}{*}{ df } & \multirow[t]{4}{*}{ p-Value } \\
\hline & & \multicolumn{6}{|c|}{ PRE-TEST OF LEVEL OF ANXIETY } & & & \\
\hline & & \multicolumn{2}{|c|}{ Mild to moderate } & \multicolumn{2}{|c|}{ Moderate to severe } & \multicolumn{2}{|c|}{ Very severe } & & & \\
\hline & & $\mathbf{n}$ & $\%$ & $n$ & $\%$ & $n$ & $\%$ & & & \\
\hline \multirow{4}{*}{ Age (in years) } & $21-30$ years & 2 & 6.67 & 6 & 20 & 2 & 6.67 & \multirow[t]{4}{*}{9.10} & \multirow[t]{4}{*}{6} & \multirow{4}{*}{$\begin{array}{c}0.168 \\
\text { NS }\end{array}$} \\
\hline & $31-40$ years & 1 & 3.33 & 7 & 23.3 & 4 & 13.33 & & & \\
\hline & $41-50$ years & 2 & 6.67 & 1 & 3.3 & 4 & 13.33 & & & \\
\hline & $\begin{array}{c}\text { Above } 50 \\
\text { years }\end{array}$ & 1 & 3.33 & 0 & 0 & 0 & 0 & & & \\
\hline \multirow{2}{*}{ Gender } & Male & 4 & 13.3 & 7 & 23.3 & 8 & 26.7 & \multirow[t]{2}{*}{2.29} & \multirow[t]{2}{*}{2} & \multirow[t]{2}{*}{0.317} \\
\hline & Female & 2 & 6.7 & 7 & 23.3 & 2 & 6.7 & & & \\
\hline \multirow{4}{*}{ Marital status } & Married & 5 & 16.7 & 6 & 20 & 6 & 20 & \multirow[t]{4}{*}{6.06} & \multirow[t]{4}{*}{6} & \multirow[t]{4}{*}{0.416} \\
\hline & Unmarried & 1 & 3.33 & 5 & 16.7 & 2 & 6.7 & & & \\
\hline & Divorced & 0 & 0 & 2 & 6.67 & 0 & 0 & & & \\
\hline & widow & 0 & 0 & 1 & 3.3 & 2 & 6.7 & & & \\
\hline \multirow{2}{*}{ Type of family } & Nuclear family & 4 & 13.3 & 6 & 20 & 6 & 20 & \multirow[t]{2}{*}{1.22} & \multirow[t]{2}{*}{2} & \multirow[t]{2}{*}{0.542} \\
\hline & Joint family & 2 & 6.67 & 8 & 26.67 & 4 & 13.33 & & & \\
\hline \multirow{3}{*}{$\begin{array}{l}\text { Monthly } \\
\text { income }\end{array}$} & >Rs.5000 & 2 & 6.7 & 4 & 13.3 & 4 & 13.3 & \multirow[t]{3}{*}{1.92} & \multirow[t]{3}{*}{4} & \multirow[t]{3}{*}{0.749} \\
\hline & Rs.5001-10000 & 3 & 10 & 8 & 26.7 & 3 & 10 & & & \\
\hline & $<$ Rs.10000 & 1 & 3.3 & 2 & 6.7 & 3 & 10 & & & \\
\hline & Illiterate & 2 & 6.7 & 7 & 23.3 & 3 & 10 & 2.29 & 4 & 0.682 \\
\hline $\begin{array}{l}\text { Educational } \\
\text { qualification }\end{array}$ & $\begin{array}{c}\text { Primary } \\
\text { education }\end{array}$ & 2 & 6.7 & 2 & 6.7 & 4 & 13.3 & & & \\
\hline & $\begin{array}{l}\text { Secondary } \\
\text { education }\end{array}$ & 2 & 6.7 & 5 & 16.7 & 3 & 10 & & & \\
\hline & Graduate & 0 & 0 & 0 & 0 & 0 & 0 & & & \\
\hline & Government & 2 & 6.67 & 5 & 16.67 & 8 & 26.67 & 6.26 & 4 & 0.181 \\
\hline Occupation & Private & 2 & 6.67 & 5 & 16.67 & 2 & 6.67 & & & \\
\hline & Business & 2 & 6.67 & 4 & 13.33 & 0 & 0 & & & \\
\hline & Others & 0 & 0 & 0 & 0 & 0 & 0 & & & \\
\hline & Urban & 5 & 16.67 & 10 & 33.33 & 7 & 23.33 & 0.389 & 2 & 0.823 \\
\hline Kesiqual & Rural & 1 & 3.33 & 4 & 13.33 & 3 & 10 & & & \\
\hline
\end{tabular}

$*_{-p}<0.05$ significant

The above table ,Association between level of anxiety and selected demographic variables were calculated by chi square in experimental group, it was observed that the level of anxiety significantly not associated in all demographic variables such as (Age $(\chi 2=9.10, p=0.168)$, gender $(\chi 2=2.29, p=0.317$ ), marital status $(\chi 2=6.06, p=0.416)$,type of family $(\chi 2=1.12, p=0.542)$, monthly income $(\chi 2=1.92, p=0.746)$,educational qualification $(\chi 2=2.29, p=0.682)$, occupation $(\chi 2=6.26, p=0.181)$, residual $(\chi 2=0.389, p=0.823)$. it might be due 


\section{ARTIC LES}

to setting of the study. Hence, accept null Hypothesis $\left(\mathrm{H}_{15}\right)$. There was not associated with all selected variables demographic variables.

Table 1.6: Association between the Pre-test of the level of anxiety among the depressed patient with their selected demographic variables in control group.

( $N=30)$

\begin{tabular}{|c|c|c|c|c|c|c|c|c|c|c|}
\hline \multirow{4}{*}{\multicolumn{2}{|c|}{ DEMOGRAPHIC VARIABLES }} & \multirow{2}{*}{\multicolumn{6}{|c|}{$\begin{array}{l}\text { CONTROL GROUP } \\
\text { PRE-TEST OF LEVEL OF } \\
\text { Anxiety }\end{array}$}} & \multirow[t]{4}{*}{$\mathrm{X} 2$} & \multirow[t]{4}{*}{ df } & \multirow[t]{4}{*}{ p-Value } \\
\hline & & & & & & & & & & \\
\hline & & \multicolumn{2}{|c|}{$\begin{array}{c}\text { Mild to } \\
\text { moderate }\end{array}$} & \multicolumn{2}{|c|}{$\begin{array}{c}\text { Moderate to } \\
\text { severe }\end{array}$} & \multicolumn{2}{|c|}{ Very severe } & & & \\
\hline & & $\mathbf{n}$ & $\%$ & $\mathbf{n}$ & $\%$ & $\mathbf{n}$ & $\%$ & & & \\
\hline \multirow{4}{*}{$\begin{array}{l}\text { Age (in } \\
\text { years) }\end{array}$} & $21-30$ years & 2 & 6.7 & 5 & 16.67 & 4 & 13.33 & \multirow[t]{4}{*}{2.05} & \multirow[t]{4}{*}{6} & \multirow{4}{*}{$\begin{array}{l}0.951 \\
\text { NS }\end{array}$} \\
\hline & $31-40$ years & 2 & 6.7 & 5 & 16.67 & 7 & 23.33 & & & \\
\hline & $41-50$ years & 1 & 3.3 & 1 & 3.33 & 2 & 6.67 & & & \\
\hline & $\begin{array}{c}\text { Above } 50 \\
\text { Years }\end{array}$ & 0 & 0 & 0 & 0 & 1 & 3.33 & & & \\
\hline \multirow{2}{*}{ Gender } & Male & 2 & 6.67 & 4 & 13.33 & 9 & 30 & \multirow[t]{2}{*}{2.16} & \multirow[t]{2}{*}{2} & \multirow[t]{2}{*}{0.339} \\
\hline & Female & 3 & 10 & 7 & 23.33 & 5 & 16.67 & & & \\
\hline \multirow{4}{*}{$\begin{array}{l}\text { Marital } \\
\text { status }\end{array}$} & Married & 2 & 6.67 & 3 & 10 & 5 & 16.67 & \multirow[t]{4}{*}{2.73} & \multirow[t]{4}{*}{6} & \multirow[t]{4}{*}{0.841} \\
\hline & Unmarried & 1 & 3.33 & 4 & 13.3 & 2 & 6.67 & & & \\
\hline & Divorced & 2 & 6.67 & 4 & 13.3 & 6 & 20 & & & \\
\hline & widow & 0 & 0 & 0 & 0 & 1 & 3.3 & & & \\
\hline \multirow{2}{*}{$\begin{array}{l}\text { Type of } \\
\text { family }\end{array}$} & Nuclear family & 2 & 6.67 & 3 & 10 & 5 & 16.67 & \multirow[t]{2}{*}{0.31} & \multirow[t]{2}{*}{2} & \multirow[t]{2}{*}{0.854} \\
\hline & Joint family & 3 & 10 & 8 & 26.67 & 9 & 30 & & & \\
\hline \multirow{3}{*}{$\begin{array}{l}\text { Monthly } \\
\text { income }\end{array}$} & >Rs. 5000 & 1 & 3.33 & 2 & 6.67 & 4 & 13.3 & \multirow[t]{3}{*}{1.94} & \multirow[t]{3}{*}{4} & \multirow[t]{3}{*}{0.746} \\
\hline & Rs.5001-10000 & 4 & 13.3 & 7 & 23.3 & 7 & 23.3 & & & \\
\hline & $<$ Rs. 10000 & 0 & 0 & 2 & 6.67 & 3 & 10 & & & \\
\hline \multirow{4}{*}{$\begin{array}{l}\text { Educational } \\
\text { qualification }\end{array}$} & Illiterate & 1 & 3.33 & 5 & 16.67 & 1 & 3.33 & 10.02 & 6 & 0.124 \\
\hline & Primary education & 0 & 0 & 2 & 6.67 & 5 & 16.67 & & & \\
\hline & $\begin{array}{l}\text { Secondary } \\
\text { education }\end{array}$ & 4 & 13.33 & 3 & 10 & 8 & 26.67 & & & \\
\hline & Graduate & 0 & 0 & 1 & 3.33 & 0 & 0 & & & \\
\hline & Government & 2 & 6.67 & 3 & 10 & 5 & 16.7 & 2.12 & 4 & 0.710 \\
\hline Occupation & Private & 2 & 6.67 & 5 & 16.67 & 3 & 10 & & & \\
\hline & Business & 1 & 3.3 & 3 & 10 & 6 & 20 & & & \\
\hline & Others & 0 & 0 & 0 & 0 & 0 & 0 & & & \\
\hline & Urban & 4 & 13.3 & 7 & 23.3 & 7 & 23.3 & 1.47 & 2 & 0.478 \\
\hline Residual & Rural & 1 & 3.3 & 4 & 13.3 & 7 & 23.3 & & & \\
\hline
\end{tabular}


The above table ,Association between level of anxiety and selected demographic variables were calculated by chi square in control group, it was observed that the level of anxiety significantly not associated in all demographic variables such as (Age $(\chi 2=2.05, p=0.951)$, gender $(\chi 2=2.16, \quad p=0.339)$, marital status $(\chi 2=2.73, p=0.841)$, type of family $(\chi 2=0.31, p=0.854)$, monthly income $(\chi 2=1.94, p=0.746)$, educational qualification $(\chi 2=10.02, p=0.214)$, occupation $(\chi 2=2.12, p=0.710)$, residual $(\chi 2=1.47, p=0.478$, , it might be due to setting of the study. Hence, accept null Hypothesis $\left(H_{15}\right)$. There was not associated with all selected demographic variables.

\section{CONCLUSION}

The findings of the study proved that Art, Dance and Film therapy on depressed patients was effective in reducing the level of anxiety and worries. The study revealed that irrespective of variations in demographic variables, all patients in experimental group showed reduction in level of anxiety and worries with depression

\section{SUMMARY}

The researcher has full satisfaction in conducting this Pilot study which focuses on the anxiety and worries on depression patients. The expert opinions, direction from the guide and help from the authorities made this pilot study useful. This study shows that Art, Dance and Film Therapy is very effective in reducing the level of anxiety and worries among depression patients.

\section{REFERENCES}

1. Febu Elizabeth Joy: Effectiveness of cognitive based mindfulness therapy on social anxiety among high school adolescents; Nitte University Journal of Health Sciences. 2014; 04(1):68-90.

2. Maryam Zargarzadeh and Maryam Shirazi. The effect of progressive muscle relaxation method on test anxiety in nursing students. Iran J Nurs Midwifery Res. 2014 Nov-Dec; 19(6): 607-612.

3. Stefan G. Hofmann, Alice T. Sawyer, Ashley A. Witt, and Diana Oh. The Effect of Mindfulness-Based Therapy on Anxiety and Depression: A Meta-Analytic Review. J Consult Clin Psychol. 2010 Apr; 78(2): $169-183$.

4. Mohammadali Hosseini , Alireza Salehi, Masoud Fallahi Khoshknab, Asghar Rokofian, Patricia Mary Davidson. The effect of a preoperative spiritual/religious intervention on anxiety in Shia Muslim patients undergoing coronary artery bypass graft surgery: a randomized controlled trial. J Holist Nurs. 2013 Sep; 31(3):164-72.

5. Singh VP, Rao V, Prem V, Sahoo RC, Keshav PK. Comparison of the effectiveness of music and progressive muscle relaxation for anxiety in COPD-A randomized controlled pilot study. Chronic Respiratory Disease. 2009 Nov 1; 6(4):209-216.

6. Song, Y., and Lindquist, R. Effects of mindfulness-based stress reduction on depression, anxiety, stress and mindfulness in Korean nursing students. Nurse Education Today. 2015; 35(1): 86-90.

7. Pesso-Aviv, T., Regev, D., and Guttmann, J. The unique therapeutic effect of different art materials on psychological aspects of 7- to 9-year-old children. Arts in Psychotherapy. 2014; 41: 293-301.

8. De Morais, A. H., Dalécio, M. A. N., Vizmann, S., Bueno, V. L. R. de C., Roecker, S., Salvagioni, D. A. J., and Eler, G. J. Effect on scores of depression and anxiety in psychiatric patients after clay work in a day hospital. The Arts in Psychotherapy. 2014; 41(2): 205-210.

9. M. Dineshkumar. Effectiveness of reminiscence therapy among old age people. Pondicherry Journal of Nursing. 2014; 7(2): 42-45.

10. Rawtaer, I., Mahendran, R., Yu, J., Fam, J., Feng, L., Kua, E.H. Psychosocial interventions with art, music, Tai Chi and mindfulness for subsyndromal depression and anxiety in older adults: a naturalistic study in Singapore. Asia Pac. Psychiatry. 2015; 7 (3): 240-250. 